\title{
STEM FROM HOME: THE TRAINING FOR PRIMARY SCHOOL TEACHERS IN BANDUNG WETAN AS A SCIENCE LEARNING ALTERNATIVE DURING THE COVID-19 PANDEMIC
}

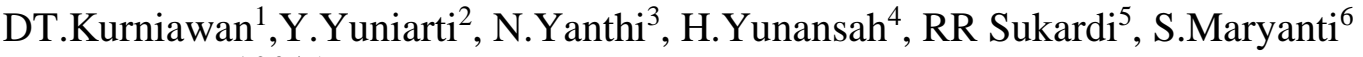 \\ 1,2,3,4,5,6PGSD UPI Kampus Cibiru, Bandung, Indonesia \\ ${ }^{7}$ Pendidikan Biologi FTK UIN Sunan Gunung Djati Bandung \\ ${ }^{1}$ dedetriekurniawan@upi.edu
}

\begin{abstract}
Abstract. This Community Service Program aims to increase the ability of elementary school teachers in Bandung Wetan district to develop STEM-based science learning plans during the Covid-19 pandemic. In detail, the objectives of this service can be described as follows: first knowing the teacher's perceptions of the implementation of STEM learning that is carried out in online learning, second knowing the teacher's needs for the implementation of STEM in online learning, the third design of the SFH training program (STEM From Home ) to improve the ability of elementary school teachers in Bandung Wetan sub-district to develop a STEM-based science learning plan during the Covid-19 pandemic and most recently as an effort to describe the ability of elementary school teachers in Bandung Wetan sub-district to develop a STEM-based science learning plan during the Covid-19 pandemic after participating in the program SFH (STEM From Home) training. This service activity targets the target audience is elementary school teachers in the Bandung Wetan district. The number of schools in Bandung Wetan District is 17 with 15 private schools and 2 public elementary schools. On this occasion, the involvement of teachers as many as 28 people was prioritized. A series of PKM activities have been carried out from August to September 2020. And Broadly speaking, the participants of the activities gave positive responses to the implementation of In House Training activities: SFH (STEM From Home) Implementation Strategies as Alternative Learning Ipa During the Covid-19 Pandemic Period for Teachers Bandung Wetan elementary school
\end{abstract}

Keywords: STEM, Study From Home, Pandemi Covid-19, Primary education

\section{A. Introduction}

Online teaching and learning activities $(\mathrm{KBM})$ were implemented in various ways by schools during the Covid-19 virus pandemic. However, the implementation is considered not optimal and shows that there is still unpreparedness among educators in adapting to this digital climate. One of them is that online learning in elementary schools has not been optimal. In fact, the education process should be carried out continuously even during a pandemic by adjusting the circumstances, one of 
which is through the use of various learning technology application platforms such as Edmodo, Ruangguru, Google Classroom, Whatssapp and so on. It is intended that the continuity of education programs for elementary school students continues in order to achieve learning objectives related to mastery of student competencies in the domain of knowledge, skills and attitudes.

The elementary school period is a period of forming the foundation of the ability to think and work through an educational process that requires a lot of attention and guidance from the environment around students. Both in normal learning situations even during the Covid-19 pandemic, this requires good collaboration between the school, in this case teachers, and parents / guardians of students in order to instill meaningful educational values for each individual student. Parental participation is very important for the success of online learning. A dilemma situation then occurs when parents cannot be there to accompany their children because they have to work, such as health workers, informal workers, factory workers, breeders, fishermen, and farmers both working from home and outside the home. While they do not have other people who can help accompany the children while studying. Parents who have the opportunity to work from home but still prioritize work also cannot help their children learn optimally. Moving on from this phenomenon, various alternative methods and methods of learning are taken simply to get the best educational outcomes for all students in the current situation. One of the learning methods that can facilitate this is the project method through science learning which involves the integration of STEM (Science, Technology, Engineering and Mathematics) in it.

Learning science using the latest context combined with project assignments is one of the lessons that can build STEM literacy. In addition, contextual learning that is packaged with strategies and media and involves technology in learning will be able to create STEM literate students. STEM literacy can bring students to interpret science as a whole, able to solve 
problems related to science and technology and engineering assisted by an understanding of mathematics. STEM literacy also leads students to become innovative and creative individuals. A person's innovation and creativity can be awakened if they are trained in creative thinking skills first, which are based on higher-order thinking, such as thinking rationally, critically and thinking creatively. STEM literacy has the potential to build people who are ready to face the 21 st century which is full of challenges and competition, both at the national and international levels.

So far, STEM learning for elementary school students has been carried out through face-to-face mode. However, during a pandemic like now, of course this cannot be done. Teachers experience confusion in implementing STEM learning into an online learning activity platform for elementary school students. As for the obstacle in implementing the implementation of online STEM learning for elementary school students is the lack of readiness of the teacher in organizing STEM learning without face to face, especially if the learning is done using the project method. Relevant to this, the success of the learning process from home needs support and cooperation from parents, so teachers need to understand how to prepare STEM-based science learning that involves parents at home to support the successful implementation of this learning.

This is also felt by teachers who teach in elementary schools in Bandung Wetan District. Generally the teachers expressed confusion and were overwhelmed by the science learning system through digital technology platforms. In addition, from the results of limited interviews, it was identified that teachers already have a basic understanding of STEM learning that they get from training activities or workshops organized by foundations, the Education Office or by government agencies (Ministry of Education and Culture). However, they are used to implementing STEM-based learning in face-to-face learning situations in the classroom. Teachers in Bandung Wetan sub-district come from 36 elementary schools with various educational 
backgrounds, but generally have a minimum education of $\mathrm{S} 1$ and $\mathrm{S} 2$ in a linear field (PGSD or basic education). Most of the teachers have followed the in-service teacher professional development program and are certified teaching profession.

Teachers who will teach science with the STEM approach must certainly have in-depth content knowledge in all fields integrated in STEM and good pedagogical skills to be able to help students achieve an in-depth understanding of STEM and how to apply this understanding in the problem solving process in their lives and careers in the future. In addition, teachers must be motivated to always participate in their professional development to help them achieve in-depth knowledge of STEM content and mastery of STEM pedagogy. In the era of the industrial revolution 4.0 and especially in this pandemic condition, teachers are also required to have digital literacy and the ability to use technology to carry out STEM learning in the concept of learning from home carried out by students. To ensure that learning is fun, full of meaning, awakens creativity, critical power, and is able to make students independent is certainly not an easy matter. Moreover, teachers cannot directly face the students. The teacher's foresight in formulating learning strategies that are able to lure students to continue to be enthusiastic about learning is something that deserves attention. If you only give students the workload, it will make them bored. Therefore, the curriculum to prepare teachers to be competent in implementing online STEM learning must emphasize competency development in both of these areas

It has clearly been explained that the development of STEM-based learning cannot be separated from the ability of teachers to design and implement it in the classroom. Therefore, a professional training program to build the ability of teachers to design and implement STEM learning is deemed indispensable. With the development of similar training, it is hoped that the ability of teachers in designing STEM-based learning will increase which is expected to have implications for student mastery in the 
four STEM fields. It should also be noted is the packaging of training programs so that they can be implemented optimally considering the policy of learning from home and working from home during the Covid-19 pandemic. Starting from this thought, the idea emerged to implement a training program for teachers called SFH (STEM Frome Home). Furthermore, through this SFH learning, it is hoped that teachers can develop innovative STEM-based science learning and motivate elementary school students to be interested in learning and exploring the STEM field.

\section{B. Method of Implementation}

In House Training program activities: SFH (STEM From Home) Implementation Strategy as an Alternative for Natural Science Learning During the Covid-19 Pandemic for Teachers Teachers at SD Bandung Wetan can be a means of expanding knowledge and providing understanding for teachers about the development of STEM learning in Indonesia. The planned activities are as follows:
First Needs analysis. The questionnaire was given through the use of Google Form to reveal data about teachers' perceptions and needs for STEM-based science learning tools development training which will be carried out online. From this data, an efficient and effective strategy and training content will be determined to develop teacher competence in developing STEM-based science learning through an online mode for elementary school students.

Second, online training through webinars using the Google Meet and Zoom applications. Activities carried out at this stage include the presentation of material on STEM education, science project-based STEM learning, and strengthening of competency in mastering material content in the four STEM fields by experts gathered in the service team. At that point, teachers are also equipped with the knowledge and skills to use educational technology 
during the online-based Covid-19 pandemic.

The three workshops and assistance in making STEM-based science learning designs online involve the use of Whatssapp Group, Google Classroom, and Instagram. This activity is mentored by experts in the STEM field in the service team continuously providing monitoring and evaluation of learning design products made by teachers. This activity allows teachers to brainstorm related STEM learning innovations at a practical level through online learning modes in discussion forums on Whatssapp groups and Google

Classroom.

In more detail, the stages of implementing this service can be shown in the following figure.

\section{Result and Discussion}

In House Training activities have been carried out: SFH (STEM From Home) Implementation Strategies as an Alternative to Learning Science During the Covid-19 Pandemic for Teachers of SD Bandung Wetan. This activity is carried out with virtual and face-to-face events through the delivery of material, demonstrations, discussions, STEMbased science practices and workshops 
on the preparation of STEM from Home learning plans which are implemented in digital learning. This activity was attended by 28 elementary school teachers around Bdung Wetan who came from 3 schools. Namely SD Istiqomah, SD Negeri Sabang and SD Negeri Periangan. The In Hose training activity arrangement is set for 32 hours of lessons which are run for 2 months with a combination of virtual face-to-face through theoretical and practical strategies.

The speakers who filled and guided this activity included the following: first, Mrs. Santi Setiani Hasanah, S.Pd., M.Pd) who conveyed about STEM-Based Learning in the 21st Century, Second Mr. Dr. Dede Trie Kurniawan, S.Si., M.Pd) who delivered STEM Learning Strategies from Home, the three mothers Novi Yanthi, S.Si., M.Pd who delivered Introduction to Engineering Design Process (EDP) and the fourth by $\mathrm{Mr}$. Rendi Restiana Sukardi, S.Pd., M.Pd) who conveyed the Making of RPP Based on the STEM Approach

In general, the activity went well and was successful. Face-to-face meetings with lecture methods, workshops and discussions facilitated by Istiqomah Elementary School run actively and well. This activity is carried out one day, namely on Monday 24 August 2020 from 08.00 WIB to $15.30 \mathrm{WIB}$. Participants in the activity totaled 28 elementary school teachers around Bdung Wetan who came from 3 schools. Namely SD Istiqomah, SD Negeri Sabang and SD Negeri Periangan.

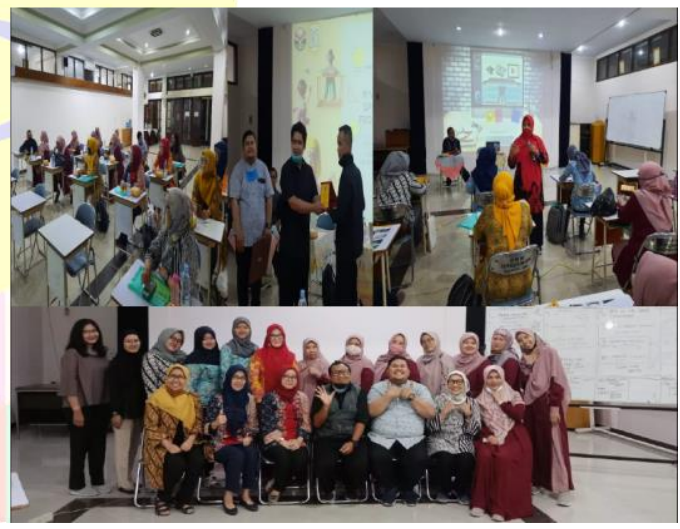

Figure 2. Documentation of Face-toFace Activities In House Training STEM From home

After the Face-to-face In House Training STEM From Home Training, the teachers do independent work which will be guided by the Whast App Group and also the Google Meet virtual face-toface within 2 weeks of completing the RPP Implementation of STEM From 
Home Implementation for Basic Education.

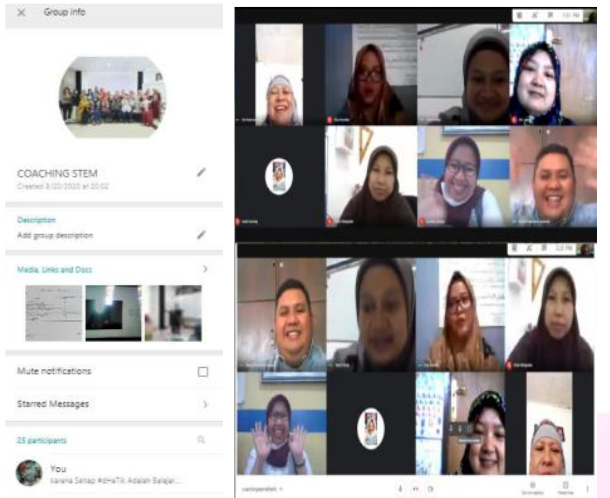

Figure 3. Documentation of Collaborative Activities with WAG and Tatap Maya Google meet

On September 18, 2020 at Istiqomah Elementary School, a closing session of in-house training was held and a certificate giving 32 lesson hours for teachers who successfully completed RPP STEM From Home according to the provisions given. In this activity, the signing of an $\mathrm{MoU}$ with SD Istiqomah and PGSD UPI Cibiru was also carried out to collaborate in the fields of teaching, research and also community service.

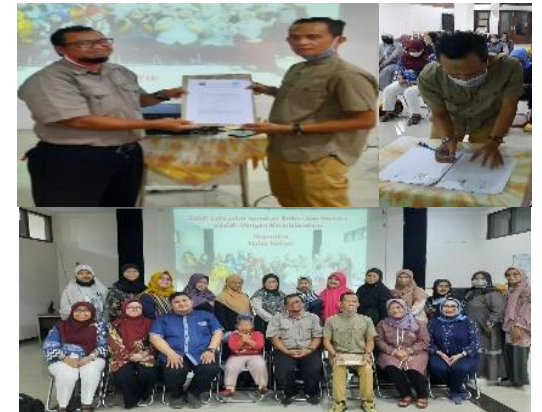

Picture 4. closing activities and signing of the MoU

From the In House Training: SFH (STEM From Home) Implementation Strategy as an Alternative to Learning Science During the Covid-19 Pandemic For Teachers, SD Bandung Wetan Teachers have produced 28 lesson plans for elementary school Thematic learning with a STEM approach that can be implemented during the learning from home policy during the COVID-19 pandemic condition. The three best RPPs will be processed for IPR to give appreciation for the work that has been made by teachers during this in house training activity.

In an effort to facilitate creative learning as long as school from home policies are implemented, In House Training: SFH Implementation Strategies (STEM From Home) as an Alternative to Learning Science During 
the Covid-19 Pandemic Period for Teachers of SD Bandung Wetan. Broadly speaking, the In House Training participants' responsiveness gave positive results and sought to have an interest in implementing SFH that was conveyed into the learning preparation from home prepared by elementary school teachers. To be able to provide an overview of effectiveness, it can be reviewed in table 1 below.

Table 1. Recapitulation of Questionnaire Response Results for Participants in STEM From Home Training

\begin{tabular}{|c|c|c|c|c|}
\hline Category & $\begin{array}{l}\text { Not } \\
\text { very } \\
\text { good } \\
(\%)\end{array}$ & $\begin{array}{l}\text { Not } \\
\text { Good } \\
(\%)\end{array}$ & $\begin{array}{c}\text { Good } \\
(\%)\end{array}$ & $\begin{array}{l}\text { Very } \\
\text { Good } \\
(\%)\end{array}$ \\
\hline $\begin{array}{l}\text { The usefulness of the } \\
\text { content presented to } \\
\text { increase the ability to } \\
\text { develop learning }\end{array}$ & 0 & 0 & 25 & 75 \\
\hline $\begin{array}{l}\text { Suitability with } \\
\text { learning content in } \\
\text { subjects }\end{array}$ & 0 & 0 & 40 & 60 \\
\hline $\begin{array}{l}\text { The effectiveness of } \\
\text { digital content } \\
\text { development with the } \\
\text { achievement of } \\
\text { learning objectives }\end{array}$ & 0 & 0 & 65 & 35 \\
\hline $\begin{array}{l}\text { The effectiveness of } \\
\text { the training method } \\
\text { with the achievement } \\
\text { of goals, especially the } \\
\text { improvement of the } \\
\text { skills of other } \\
\text { participants }\end{array}$ & 0 & 0 & 40 & 60 \\
\hline
\end{tabular}

\begin{tabular}{cccc}
\hline Category & Not & \multicolumn{2}{c}{ Not Good Very } \\
very & Good $(\%)$ & Good \\
good & $(\%)$ & $(\%)$ \\
$(\%)$ & & & \\
\hline
\end{tabular}

Support for improving student understanding if learning content is $\quad \begin{array}{llll}0 & 0 & 70 & 30\end{array}$ packaged in this application or format

It can be seen in the thickness of 1 category with the highest presentation in the field of usefulness of the content presented to increase the ability to develop learning. However, it needs to be addressed and improved in the effectiveness of developing digital content by achieving learning objectives

\section{Conclusion}

In Genral, the implementation of the In House Training Program: SFH (STEM From Home) Implementation Strategy as an Alternative to Natural Science Learning During the Covid-19 Pandemic For Teachers, SD Bandung Wetan Teachers can be categorized as successful and running well. This can be shown by mostly giving positive results and trying to have an interest in implementing $\mathrm{SFH}$ that is conveyed into learning preparation from home prepared by elementary school teachers. Teachers and principals who reveal that this activity is very good 
because it can provide benefits and broaden their horizons regarding the integration of learning that links elements of science, technology, religion, engineering, art and mathematics in a thematic learning activity for students during the policy period of learning from home during the period. pandemic COVID -19 .

\section{REFERENCES}

Hamdani, A. R., \& Priatna, A. (2020). EFEKTIFITAS IMPLEMENTASI PEMBELAJARAN DARING (FULL ONLINE) DIMASA PANDEMI COVID-19 PADA JENJANG SEKOLAH DASAR DI KABUPATEN SUBANG. Didaktik: Jurnal Ilmiah PGSD STKIP Subang, 6(1), 1-9.

Kurniasari, A., Pribowo, F. S. P., \& Putra, D. A. (2020). ANALISIS EFEKTIVITAS PELAKSANAAN BELAJAR DARI RUMAH (BDR)
SELAMA PANDEMI COVID-

19. Jurnal Review Pendidikan Dasar: Jurnal Kajian Pendidikan dan Hasil Penelitian, 6(3), 246-253.

Fitriyani, Y., Fauzi, I., \& Sari, M. Z. (2020). Motivasi Belajar Mahasiswa Pada Pembelajaran Daring Selama Pandemik Covid-19. Jurnal

Kependidikan: Jurnal Hasil Penelitian dan Kajian Kepustakaan di Bidang Pendidikan, Pengajaran dan Pembelajaran, 6(2), 165-175.

Lestari, P. A. S., \& Gunawan, G. (2020). The Impact of Covid-19 Pandemic on Learning Implementation of Primary and Secondary School Levels. Indonesian Journal of Elementary and Childhood Education, 1(2), 58-63.

Pramada, R., BURSTIANDO, R., \& PUTRA, R. P. (2020). HUBUNGAN 
DUKUNGAN ORANG TUA Lilawati, A. (2020). Peran Orang Tua

DENGAN MOTIVASI BELAJAR

SISWA DALAM MENGIKUTI

PEMBELAJARAN

PENJAS

SECARA DALAM JARINGAN

(DARING) SAAT PANDEMI

COVID-19 DI MI SURYA UTAMA

AL FAJAR DESA KEREP (Doctoral

dissertation, Universitas Nusantara

PGRI Kediri).

Kim, Y. \& Park, N. (2012). The Effect of STEAM Education on Elementary School Student's Creativity Improvement. CCIS 339: 115-121. DOI: $\quad$ 10.1007/978-3-642-352645_16.

Nugraheny, A. R. (2020). PERAN TEKNOLOGI, GURU DAN ORANG TUA DALAM PEMBELAJARAN DARING DI MASA PANDEMI. dalam Mendukung Kegiatan

Pembelajaran di Rumah pada Masa

Pandemi. Jurnal Obsesi: Jurnal

Pendidikan Anak Usia Dini, 5(1), 549-558.

Becker, K., \& Park, K. (2011). Effects of integrative approaches among science , technology, engineering, and mathematics ( STEM ) subjects on students learning : A preliminary meta-analysis. Journal of STEM Education, $\quad$ 12(5), 23-38. https://doi.org/10.1037/a001945

Permanasari, Anna. 2017. STEM Education : Inovasi Pembelajaran Sains dalam menapaki pendidkan Abad 21. Prosiding Semnas Pendidikan IPA VIII

Hendriani, Yeni. 2018. Pendidikan STEM, Outcome dan Hambatan 
untuk implementasinya.

https://p4tkipa.kemdikbud.go.id/blog

/index.php/2018/06/26/pendidikan-

stem-outcome-dan-hambatan-untuk-

impementasinya/

Sriyati, Siti. D. Rochintaniawati, A. Widodo, Widi Purwaningsih, Riandi. 2018. Upaya Mengembangkan Kemampuan Guru Kota BandungDan Sekitarnya Untuk Mendesain Pembelajaran Berbasis Stem (Science Technology, Engineering And Mathematics) Melalui Kegiatan Lokakarya. Prosiding Seminar
Nasional Hasil PKM LPM UNPAS.

ISBN 978-602-0942-254

Neville, T. (2005). Postlethwaite Educational research: some basic concepts and terminology. International Institute for Educational Planning/UNESCO, p 9.

Harefa, N., Gultom, S., \& Purba, L. S. L. (2019). Implementasi webinar terhadap sikap sadar keamanan kimia mahasiswa. Jurnal Dinamika Pendidikan, 12(1), 17-28. 